\title{
Advance in Antibacterial Magnesium Alloys and Surface Coatings on Magnesium Alloys: A Review
}

\author{
Yang Shao ${ }^{1} \cdot$ Rong-Chang Zeng ${ }^{1,2} \cdot$ Shuo-Qi Li ${ }^{1} \cdot$ Lan-Yue Cui $^{1} \cdot$ Yu-Hong Zou ${ }^{3}$. Shao-Kang Guan ${ }^{2} \cdot$ Yu-Feng Zheng ${ }^{4}$
}

Received: 16 January 2020 / Revised: 23 February 2020 / Published online: 14 April 2020

(c) The Chinese Society for Metals (CSM) and Springer-Verlag GmbH Germany, part of Springer Nature 2020

\begin{abstract}
Magnesium (Mg) alloys as a bioabsorbable light metal have shown great clinical potential as bone replacement implants. In this review, the categories, progress in cutting-edge preparation technologies and antibacterial mechanisms of $\mathrm{Mg}$ alloys and considerable numbers of corrosion-resistant and functional coatings are summarized. The relationship among the microstructure (grain size, intermetallic compounds), biocorrosion resistance and biocompatibility for antibacterial $\mathrm{Mg}$ alloys is discussed. The challenge and outlooks of biomedical Mg alloys and coatings are proposed from an antibacterial perspective.
\end{abstract}

Keywords Magnesium alloys $\cdot$ Antibacterial properties $\cdot$ Coatings $\cdot$ Degradation $\cdot$ Biomaterial

\section{Introduction}

The history of metallic materials as medical implants dates back to the nineteenth century [1]. The industrial revolution during this period has greatly promoted the development of metal industry. At the same time, it was also a time of raging war, and a large number of wounded soldiers needed surgery or treatment. The development of metal implants was mainly driven by people's attempts to repair bones. Until the successful implementation of Lister's aseptic surgery in 1860s [2], metallic materials began to play a predominant role in plastic surgery. The early implanted metals were mostly iron, copper and silver, which have a long usage history. However, such metal implants are non-biodegradable, which means

Article note must: Available online at http://link.springer.com/ journal/40195.

Rong-Chang Zeng

rczeng@foxmail.com

1 Corrosion Laboratory for Light Metals, College of Materials Science and Engineering, Shandong University of Science and Technology, Qingdao 266590, China

2 School of Materials Science and Engineering, Zhengzhou University, Zhengzhou 450002, China

3 College of Chemical and Environmental Engineering, Shandong University of Science and Technology, Qingdao 266590, China

4 Department of Materials Science and Engineering, College of Engineering, Peking University, Beijing 100871, China that they will remain in the human body after completing clinical needs or be removed through subsequent processes. Permanent implants can cause a series of problems, such as long-term endothelial dysfunction, permanent physical irritation, and chronic inflammatory local reactions [3]. Degradable implants have attracted increasing interest in the past few years. Such materials can replace the clinical function of permanent implants and, once completed, they disappear completely through degradation when the device is no longer used [4]. When selecting implant materials, the following conditions should also be met. Firstly, the implants must have good adaptability to human tissues and fluids, which means that the implants are non-toxic and non-irritating to the tissue and do not affect the normal metabolic activity [5]. Secondly, they must have a certain chemical stability, which will not change in the biological environment, and not affected by biological enzymes [6]. In addition, they must withstand various mechanical actions of human body, which requires them to have appropriate strength, toughness, wear resistance, etc. in mechanics [7].

$\mathrm{Mg}$ is an extremely light metal. The density of $\mathrm{Mg}$ is $1.74 \mathrm{~g} / \mathrm{cm}^{3}$, which is 1.6 and 4.5 times lower than that of aluminum and steel, respectively. $\mathrm{Mg}$ alloys are promising material in medical implants due to their low density, natural biodegradability [4], similar elastic modulus to bone and good biocompatibility [8].

Microbial infections have been observed on implants because of bacterial adhesion to implant surfaces. Biofilms produced by bacterial metabolism are resistant to 
the immune system and antibiotics, which brings lots of clinical challenges [9]. Infection may lead to inflammation around the tissue, requiring additional surgery and repair of the implant, causing secondary damage to the patient and increasing the patient's medical burden [10]. Studies have shown that bone implant materials will form biofilms on the surface of the fixed devices after implanting in the human body. Bacterial biofilm is a microbial cell colony that is irreversibly adhered to a biological or abiotic surface in a matrix of primarily polysaccharide material [11]. Bacterial adhesion and subsequent biofilm formation (Fig. 1) are the first steps in bacterial colonization leading to bone infection. In addition, after forming biofilms on the implant surface, attached bacteria become difficult to resist immune surveillance [12]. Once bacterial infection occurs, bacteria will hardly be attacked by the immune system due to the presence of biofilm [13]. Moreover, antibiotics will also be difficult to remove these bacteria [14]. It is estimated that about two-thirds of human bacterial infections are caused by bacterial biofilms [15]. Regardless of the complexity of

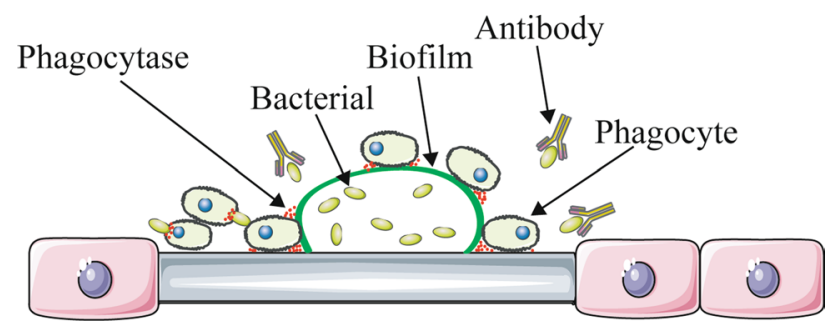

Fig. 1 Biofilm causes infection: planktonic bacteria can be eliminated by antibodies and phagocytes, while bacterial cells that adhere to the surface of the implant form a biofilm. The biofilm protects bacteria inside the membrane and attracts phagocytes to it. Phagocytosis is frustrated, but phagocytose are released, which can damage the tissues surrounding the biofilm and cause infection [13] implant, all medical devices are susceptible to microbial colonization and infection [16].

Research on antibacterial properties of biomedical materials is of great significance. It can not only improve the overall performance of such materials, and expand its clinical application range, but also greatly help improve the health and medical volume of the whole society in the long run. Research efforts are currently contributed to eliminating or reducing infection of biomedical materials. Although some effective methods related to both areas have been studied in recent years, deep and systematic research is still needed, mainly due to the differences in implant environment and bacterial attachment [17]. The focus of this review is concentrated on the state-of-the-art advance and development in science and engineering of antibacterial $\mathrm{Mg}$ alloys and coatings on biodegradable $\mathrm{Mg}$ alloys, with the intent to reducing and controlling the risk of bacterial infections while taking into account other properties.

\section{Antibacterial Mg Alloys and Coatings}

Basically, antibacterial $\mathrm{Mg}$ alloys are classified into $\mathrm{Mg}-\mathrm{Ag}$, $\mathrm{Mg}-\mathrm{Cu}, \mathrm{Mg}-\mathrm{Zn}$ and $\mathrm{Mg}-\mathrm{Ga}$, etc.[18]; and antibacterial coatings include inorganic coatings [19,20] (oxide/nitride coating, diamond-like carbon (DLC)), organic coatings (chitosan (CS), tannic acid (TA), antibiotic and peptides as well as polyurethane (PU)) and their composites, as shown in Fig. 2.

\subsection{Antibacterial Mg Alloys}

Several reports claimed that the good antibacterial activity of pure $\mathrm{Mg}$ due to degradation in vivo and in vivo is mainly associated with increased $\mathrm{pH}$ value [21, 22]. Robinson et al. [23] studied the antibacterial properties of $\mathrm{Mg}$ against three

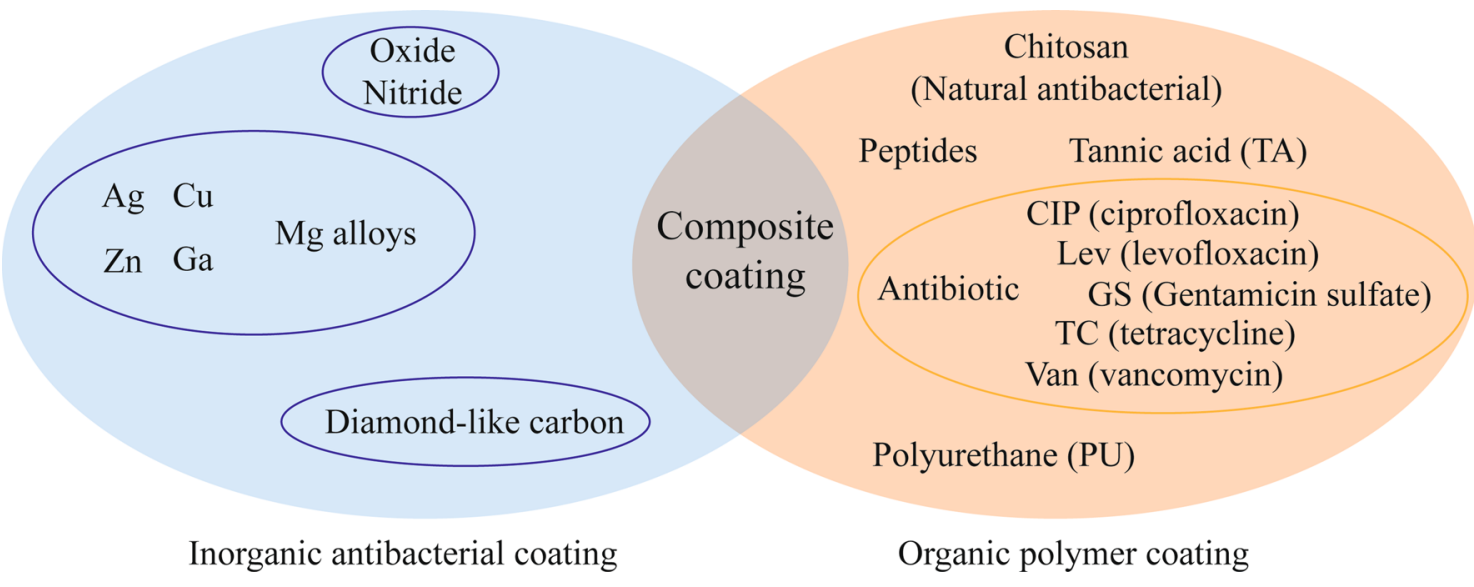

Fig. 2 Classification of antibacterial Mg alloys and coatings 
different bacteria (Escherichia coli (E. coli), Pseudomonas aeruginosa and Staphylococcus aureus (S. aureus)). It was found that the $\mathrm{pH}$ value and $\mathrm{Mg}$ ion concentration did not change with the mass of the added $\mathrm{Mg}$, and the survival colony-forming units (CFU) of all three bacteria decreased. Simultaneously, the degradation of $\mathrm{Mg}$ increases the concentration of $\mathrm{Mg}$ ions. And Jesú et al. [24] found that Mg ions showed a significant antibacterial effect on Staphylococcus epidermidis and E. coli. The antibacterial effect is mainly due to the increase in osmotic pressure around bacterial cells by $\mathrm{Mg}$ ions. However, due to the presence of biofilms, bacterial cells can withstand external $\mathrm{pH}$ changes and cause tissue infection. Therefore, according to the complex physiological environment of the implant, only the change in $\mathrm{pH}$ values cannot achieve excellent antibacterial performance. Moreover, the degradation behavior of pure $\mathrm{Mg}$ in body fluids must be taken into consideration. Adults' daily intake of $\mathrm{Mg}$ is between 300 and $400 \mathrm{mg}$ [25]. Once the corrosion rate of $\mathrm{Mg}$ is too fast, it will not only produce high concentrations of $\mathrm{Mg}^{2+}$ ions and cause hypermagnesemia [26], but also produce enormous amount of hydrogen gases. So far, scientists have developed a variety of novel $\mathrm{Mg}$ alloys with antibacterial properties through elemental alloying.

$\mathrm{Mg}$ alloys, alloying with antibacterial metallic elements such as $\mathrm{Ag}, \mathrm{Zn}$ and $\mathrm{Cu}$, are promising biomaterials candidates for implantable devices [27]. Ag [28, 29], Zn [30] and $\mathrm{Cu}$ [31] have certified ability to suppress bacterial activities. Table 1 lists the effects of the addition of different alloying elements on the antibacterial properties of Mg alloys. Antibacterial metallic elements are shown in Fig. 3. Although there are many metallic elements that can kill bacteria, due to the toxicity of $\mathrm{Hg}, \mathrm{Cd}, \mathrm{Pb}$ and $\mathrm{Cr}$, the metals used as metal fungicides are mainly $\mathrm{Ag}, \mathrm{Cu}$ and $\mathrm{Zn}$. The presence of antibacterial metal ions makes bacterial cells in a high ion concentration environment, which can change the bacterial membrane potential and disrupt their molecular or electron transport [32]. In addition, although some are very toxic, the elements with antibacterial properties are relatively concentrated in the groups of IB, IIB and the third horizontal row or long period in the periodic table (Fig. 3). It is noted that most of them are the transition metals, which have unfilled $d$ electron shell and one or two valence electrons in the next higher energy shell (i.e., $s$ state), except for $\mathrm{Mg}, \mathrm{Ga}$ and $\mathrm{Pb}$. Adjacent elements in the same group may have similar structure and properties, so it is speculated that indium may also have antibacterial ability. However, no research has shown that indium or its compounds can kill bacteria, but some studies have shown that doping indium ions in nano-sized $\mathrm{ZnO}$ can reduce the average grain size of $\mathrm{ZnO}$ and exert its maximum antibacterial activity [33]. Perhaps in the future, scientists can seek regularity from the periodic table of elements to find more elements with antibacterial properties or enhance the antibacterial ability of other elements.

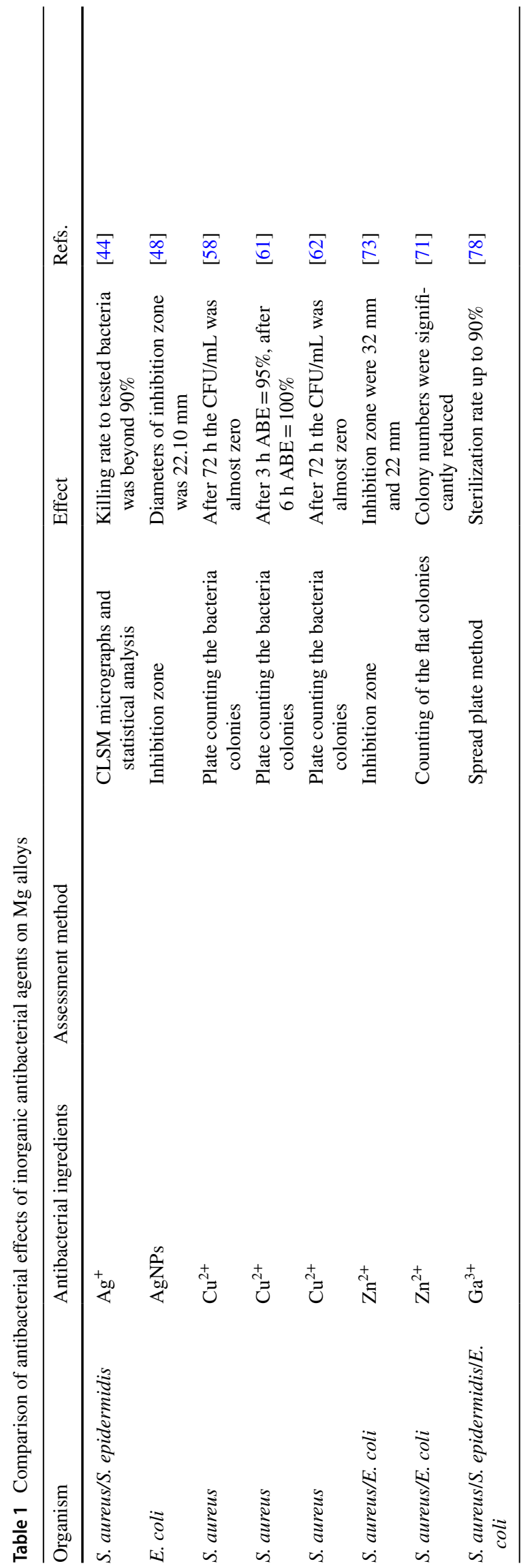




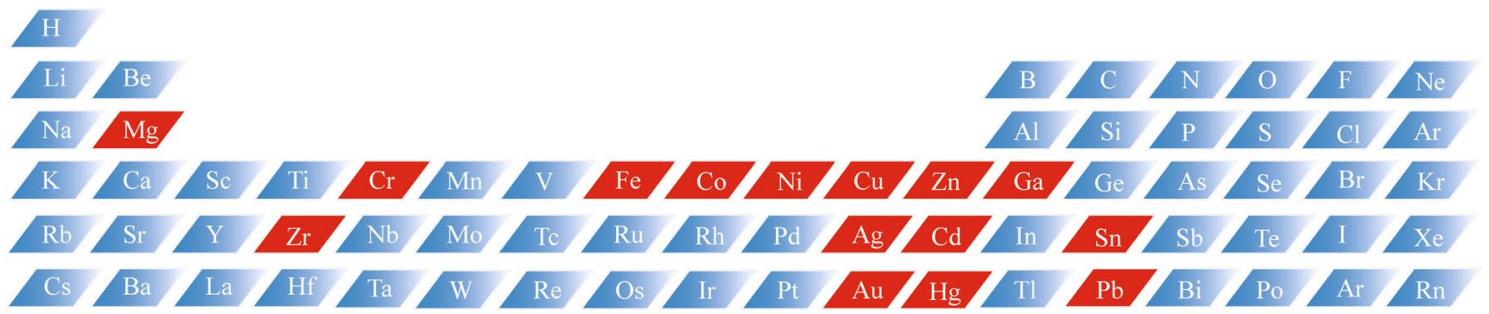

Fig. 3 Metal ions (in red color) can kill and inhibit pathogen activity

\subsubsection{Mg-Ag}

Silver $(\mathrm{Ag})$ metal has a long history as precious metal, and been used for about 7000 years [34]. Its use in coins and cutlery may be related to its corrosion resistance and antibacterial properties [35]. Herodot [36] has mentioned therefore the introduction of antibiotics. Not only can $\mathrm{Ag}^{+}$ions kill bacteria, but their salts and nanoparticles also have antibacterial properties $[37,38]$. The antibacterial mechanism of $\mathrm{Ag}^{+}$ions is shown in Fig. $4 \mathrm{Ag}^{+}$ions strongly attract the thiol groups $\left(\mathrm{SH}^{-}\right)$of enzyme proteins in the bacteria and bind them together quickly, as shown in Eq. (1). Hence, the enzyme that has this essential $\mathrm{SH}^{-}$group loses its activity and the bacteria have to die [39].

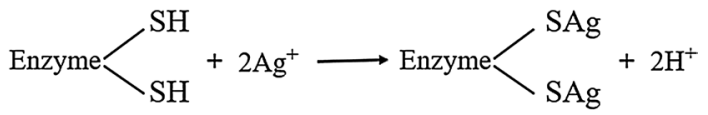

Once bacteria are killed, $\mathrm{Ag}^{+}$ions will free from the dead bacteria and contact with other colonies. Therefore, $\mathrm{Ag}^{+}$ ions can trigger a new round of antibacterial process, which is why they have long-lasting antibacterial properties [40, 41]. There are two main mechanisms (Fig. 5) responsible for the antibacterial activity of Ag. One is the combination of $\mathrm{Ag}^{+}$ions and bacterial RNA, DNA, which inhibit their reproduction [42]. Another mechanism may be that $\mathrm{Ag}^{+}$ ions bind to the proteins on the bacterial walls and enter the cytoplasm, causing changes in bacterial structure toward apoptosis [43].

Di et al. [44] proposed that solid solution (T4) and aging treatment (T6) have an impact on the antibacterial activity of the castMg2 Ag, Mg4 Ag and Mg6Agalloys that contain 1.87, 3.82 and $6.00 \mathrm{wt} \% \mathrm{Ag}$. The $\mathrm{Mg} 2 \mathrm{Ag}, \mathrm{Mg} 4 \mathrm{Ag}$ and Mg6Ag alloys have average grain size of $600 \mu \mathrm{m}, 480 \mu \mathrm{m}$ and $350 \mu \mathrm{m}$, respectively. Namely, the grain size of $\mathrm{Mg}-(2$, $4,6) \mathrm{Ag}$ alloys decreases with $\mathrm{Ag}$ concentration. The second phases or intermetallic compounds of the cast $\mathrm{Mg}-\mathrm{Ag}$ alloys are $\mathrm{Mg}_{4} \mathrm{Ag}$ (or $\beta$ phase) and $\mathrm{Mg}_{54} \mathrm{Ag}_{17}$. Silver-enriched dendrites and $\beta$ phase are distributed along the grain boundaries with a size of from hundreds of nanometer to several micrometers. In particular, $\mathrm{Mg}_{54} \mathrm{Ag}_{17}$ were observed in

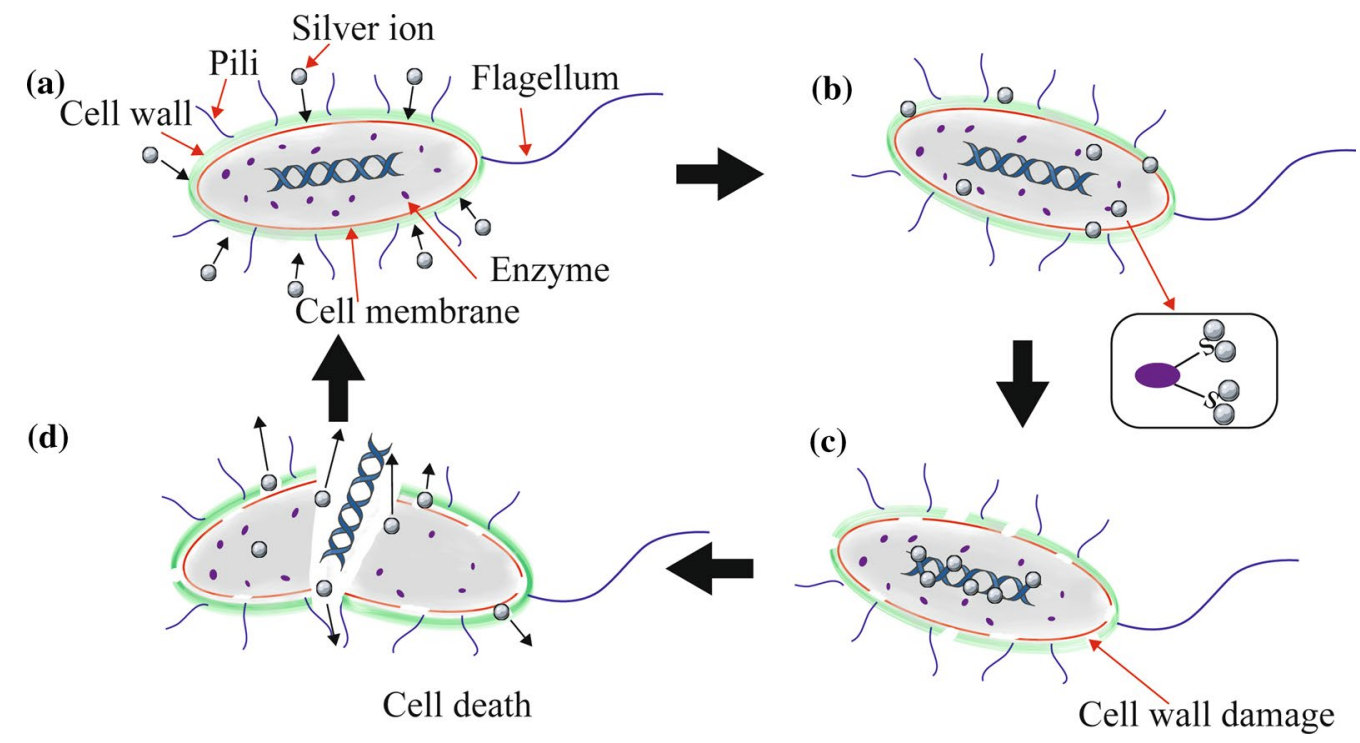

Fig. 4 Schematic illustration of antibacterial mechanism of Ag ions 
Cell membrane

(a)

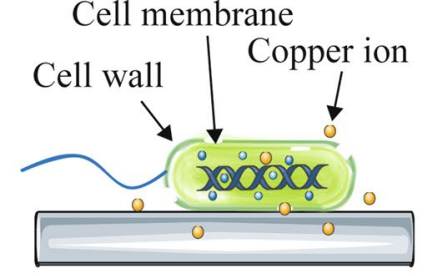

(c)

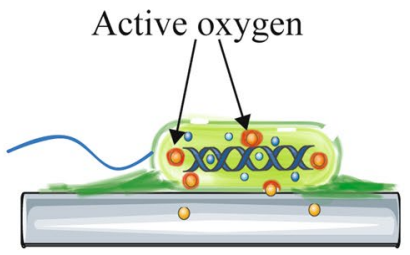

(b)

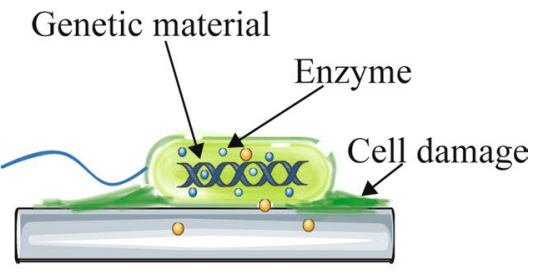

(d)

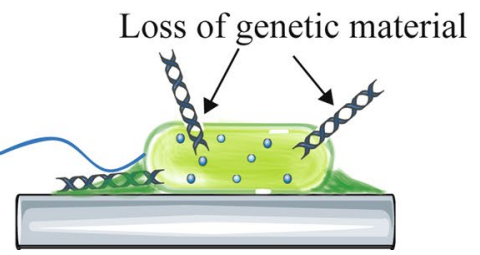

Fig. 5 Schematic illustration of antibacterial mechanism of copper ions

Mg6Ag alloy. Therefore, the mechanical properties of the $\mathrm{Mg}-\mathrm{Ag}$ alloys are improved with addition of $\mathrm{Ag}$. Most of the $\mathrm{Mg}_{4} \mathrm{Ag}$ phase can be solid-soluted or dissolved into $\alpha-\mathrm{Mg}$ matrix by $\mathrm{T} 4$ treatment. After $\mathrm{T} 6$ treatment, the $\mathrm{Mg}_{4} \mathrm{Ag}$ can be re-precipitated. The corrosion rate of the $\mathrm{Mg}-\mathrm{Ag}$ alloys is in the decreasing order: the cast $>\mathrm{T} 6>\mathrm{T} 4$. The lowest biodegradation rate was found for $\mathrm{T} 4$-treated $\mathrm{Mg} 2 \mathrm{Ag}$ alloy with a corrosion rate of $0.343 \mathrm{~mm} / \mathrm{year}$ that is inferior to pure cast $\mathrm{Mg}(0.534 \mathrm{~mm} /$ year). These $\mathrm{Mg}-\mathrm{Ag}$ alloys demonstrate good antibacterial performance with markedly reduced viable bacterial counts (by 50-75\%) and bacterial activity (by $74-79 \%$ ) with regard to titanium and glass. The antibacterial assays result showed that in $\mathrm{Mg} 4 \mathrm{Ag}$ alloy the killing rate exceeds $90 \%$ against S. aureus and Staphylococcus epidermidis. These findings suggest that T4-treated $\mathrm{Mg} 2 \mathrm{Ag}$ and $\mathrm{Mg} 4 \mathrm{Ag}$ alloys show the most promising potentials as antibacterial bioabsorbable materials based on the excellent balance achieved in manipulating mechanical, degradable and cytocompatible and antibacterial properties.

Similar results also have been conducted by Peng et al. [45], who manufactured $\mathrm{Mg}-1 \mathrm{Zn}$ alloys with a trace of $\mathrm{Ag}$ : $\mathrm{Mg}-1 \mathrm{Zn}-0.21 \mathrm{Ag}, \mathrm{Mg}-1 \mathrm{Zn}-0.47 \mathrm{Ag}$ and $\mathrm{Mg}-1 \mathrm{Zn}-0.79 \mathrm{Ag}$. The concomitant extrusions predominantly consist of refined grain boundaries and $\alpha-\mathrm{Mg}$ matrix. The grain size is reduced with an augment in Ag content due to recrystallization. This result is in good accordance with the finding conducted by Di et al. [44]. The addition of Ag element improves the mechanical properties significantly. It is noteworthy that the width of grain boundary is increased with the increment of $\mathrm{Ag}$ content, which is mostly related to reduced corrosion resistance. The convex-shaped corrosion morphology in localized sites designates the occurrence of galvanic corrosion during the immersion. But the state of $\mathrm{Ag}$, in solid solution or intermetallic compounds, is not mentioned in the context.
In addition, $\mathrm{Ag}$ nanoparticles have proven to be effective antibacterial agents [46, 47]. Zeng et al. [48] employed self-assembly technology to prepare an antibacterial composite coating by fixing Ag nanoparticles (AgNPs) on the surface of 3-aminopropyltrimethoxysilane (APTMS)modified AZ31 Mg alloy (APTMS/Mg). Antibacterial experiment results showed that the diameter of inhibition zones of AgNPs/APTMS/Mg substrates against $E$. coli was $22.10 \mathrm{~mm}$, which implies good antibacterial activity. Notably, besides the bactericidal properties of AgNPs, the amino groups of APTMS could also act as bactericides by inducing phase separation of charged and uncharged lipids inside the cytoplasm membrane of bacteria [49].

\subsubsection{Mg-Cu alloy}

$\mathrm{Cu}$ is an essential element and promoting metabolism of human body, and one of the elements used in biomedical applications. Also, $\mathrm{Cu}$-bearing compounds have a variety of biological effects, including anti-inflammatory and antiproliferative [50].

Antibacterial use of copper $(\mathrm{Cu})$ experiences a long history. In the nineteenth century, Milharde [51] used Bordeaux mixture to fight the mildew disease of vines. Subsequently, Swedish scientists [52] discovered that water solution with a trace of $\mathrm{Cu}^{2+}$ ions possesses an antibacterial function. Then the increasing number of literature suggests the antibacterial function of $\mathrm{Cu}^{2+}$ ions and antibacterial mechanism [53, 54]. Recently, Burghardt et al. [55] revealed the dual function of $\mathrm{Cu}^{2+}$ ions, which can inhibit bacterial infections at higher concentrations and promote bone regeneration at lower concentrations. The antibacterial mechanism of $\mathrm{Cu}^{2+}$ ions (Fig. 5) consists of two steps: $\mathrm{Cu}^{2+}$ ions that eluted from the material's surface are absorbed onto the surface of bacteria 
cells; then $\mathrm{Cu}^{2+}$ ions damage the cell membrane and solidify the structure of proteins [56, 57].

Liu et al. [58] designed three biodegradable $\mathrm{Mg}-(0.03$, $0.19,0.57 \mathrm{wt} \%) \mathrm{Cu}$ alloys as bone repair materials. The microstructure of $\mathrm{Mg}-\mathrm{Cu}$ alloys is characterized by $\alpha-\mathrm{Mg}$ matrix and a trace of $\mathrm{Mg}_{2} \mathrm{Cu}$. The intermetallic compound results in severe galvanic corrosion between the $\alpha-\mathrm{Mg}$ matrix $/ \mathrm{Mg}_{2} \mathrm{Cu}$. As a result, $\mathrm{Mg}-0.57 \mathrm{Cu}$ alloy has the highest corrosion rate. In addition, antibacterial experiments showed that all of $\mathrm{Mg}-\mathrm{Cu}$ alloys exhibit good antibacterial properties. The main antibacterial mechanism is the high $\mathrm{pH}$ environment produced by the degradation of $\mathrm{Mg}$ alloy and the release of $\mathrm{Cu}^{2+}$ ions. In addition, it also calculated the amount of $\mathrm{Cu}^{2+}$ ions released from $\mathrm{Mg}-0.57 \mathrm{Cu}$ to confirm its cytotoxicity. The results showed that the $\mathrm{Cu}$ released amount was about $0.67 \mathrm{mg} /$ day, if the $\mathrm{Mg}-0.57 \mathrm{Cu}$ implant with a size of $\Phi 10 \times 3 \mathrm{~mm}^{3}$ was implanted into the body. This value is lower than the recommended daily intake $(0.9 \mathrm{mg})$ and the tolerable upper limit $(10 \mathrm{mg})$ [59], indicating that the $\mathrm{Mg}-0.57 \mathrm{Cu}$ alloy exhibits great antibacterial performance and acceptable biocompatibility. In addition, $\mathrm{Li}$ et al. [60] investigated the antibacterial activity of $\mathrm{Mg}-(0.05$, 0.1 and $0.25 \mathrm{wt} \%) \mathrm{Cu}$ alloys, aiming to cure chronic osteomyelitis (bone inflammation) induced by methicillin-resistant Staphylococcus aureus. As expected, the $\mathrm{Mg}-0.25 \mathrm{Cu}$ alloy showed the best antibacterial activity among the alloys, with tolerant biocompatibility. These results disclosed that the antibacterial capability of $\mathrm{Mg}-\mathrm{Cu}$ alloys relates to the released content of copper ions. That is, the higher the content of $\mathrm{Cu}$ in $\mathrm{Mg}-\mathrm{Cu}$ alloy, the better the antibacterial performance. However, the high concentration of $\mathrm{Cu}$ in $\mathrm{Mg}$ alloys inevitably results in rapid biodegradation rate of the alloys due to the great difference in potential of $\mathrm{Mg}$ and $\mathrm{Cu}$, which is an intrinsic impurity element of $\mathrm{Mg}$. The degradation rate of $\mathrm{Mg}-\mathrm{Cu}$ alloys can be decreased via the following strategies [61]: (1) micro-alloying of $\mathrm{Cu}$, (2) grain-refining and heat treatment, (3) coating preparation. For instance, $\mathrm{Xu}$ et al. [62] prepared ZK30-(0.1, 0.2, $0.3 \mathrm{wt} \%) \mathrm{Cu}$ alloys using selective laser cladding. It is found that the obtained alloy has good antibacterial properties. And the refined grains give rise to an improved biodegradation resistance.

\subsubsection{Mg-Zn}

Zinc $(\mathrm{Zn})$ is an essential trace element required for bone formation and plays a vital role in osteoblast activity and collagen synthesis [63, 64]. In addition, Zn possesses excellent antibacterial ability [65]. Related studies have found that $\mathrm{Zn}^{2+}$ ions could react with sulfhydryl groups to inhibit bacterial activities such as transmembrane proton transfer, glycolysis and acid resistance [66]. Due to these excellent properties, the addition of $\mathrm{Zn}$ to implant materials has attracted scientists' attention [67].
A considerable amount of literature has been concerned with the corrosion and biocompatibility of $\mathrm{Mg}-\mathrm{Zn}$ alloys, i.e., $\mathrm{Mg}-6 \mathrm{wt} \% \mathrm{Zn}$ [68] and $\mathrm{Mg}-2 \mathrm{Zn}-0.2 \mathrm{Mn}-x \mathrm{Nd}$ [69]. Nevertheless, sparse literature involves the antibacterial activity and inflammatory response of $\mathrm{Mg}-\mathrm{Zn}$ alloys. Cipriano et al. [70] firstly reported the in vitro transient inflammatory response of endothelial cells to the degradation products of $\mathrm{Mg}-4 \mathrm{Zn}-x \mathrm{Sr}$ alloys $(x=0.15,0.5,1.0,1.5 \mathrm{wt} \%)$.

In addition to $\mathrm{Mg}-\mathrm{Zn}$ alloys, combining $\mathrm{Zn}$ ions as a coating on the surface of $\mathrm{Mg}$ alloy can also exert its antibacterial effect. Yang et al. [71] added both $\mathrm{Zn}^{2+}$ and $\mathrm{Sr}^{2+}$ ions into the solution of hydrothermally modifying $\mathrm{Mg}$ alloy ZK60 surface to improve the antibacterial performance and osteocyte differentiation. The results showed that the number of bacteria colonies on the surface of $\mathrm{Zn}$-containing $\mathrm{Mg}$ alloys significantly declines, suggesting that $\mathrm{Zn}^{2+}$ ions play a crucial role in inhibiting both $E$. coli and $S$. aureus. It is also worth noting that the addition of $\mathrm{Sr}^{2+}$ ions promotes osteogenic differentiation [72], which greatly shortens the recovery time of fracture patients.

Zou et al. [73] prepared a Zn-loaded montmorillonite (Zn-MMT) coating on the surface of Mg alloy AZ31 by hydrothermal method. Antibacterial ability test results showed the diameters of the inhibition zone of Zn-MMT coating against both $E$. coli and $S$. aureus were, respectively, $22 \mathrm{~mm}$ and $32 \mathrm{~mm}$, which was equivalent to the expected results. They also plotted the cumulative release curves of $\mathrm{Zn}^{2+}$ ions. The release curves can be divided into two stages: In the first $96 \mathrm{~h}$ (the first stage), $\mathrm{Zn}^{2+}$ ions were released at a constant rate. After $96 \mathrm{~h}$ (the second stage), the amount of $\mathrm{Zn}^{2+}$ ion released was significantly reduced. It is worth noting that although the release of $\mathrm{Zn}^{2+}$ is significantly reduced, the antibacterial effect of Zn-MMT coatings still exists. This long-lasting antibacterial property is attributed to the advantages of high cation exchange and adsorption of MMT structures [74].

\subsubsection{Mg-Ga}

Gallium $(\mathrm{Ga})$ is a trivalent transition metal, whose ionic radius is close to the radius of iron atoms. To date, some studies suggested that $\mathrm{Ga}^{3+}$ ions have antibacterial properties $[75,76]$. The reason for bacterial death is mainly related to the close atomic radius of $\mathrm{Ga}$ and $\mathrm{Fe}$. Trivalent iron $\left(\mathrm{Fe}^{3+}\right)$ ions are extremely important for the reproduction and colonization of the most of bacteria; and they play a vital role in DNA synthesis, while Ga can bind to the transferrin in cells, which affects Fe metabolism of cells and thus inhibits cell growth [77].

Gao et al. [78] proposed a new strategy for addressing the bone-implant-related infection through micro-alloying of $\mathrm{Ga}$ and/or $\mathrm{Sr}$ in $0.1 \mathrm{wt} \%$ that is far below their solid solubility in $\mathrm{Mg}$. Because of the extremely low concentration of Ga and 
$\mathrm{Sr}$, there are no intermetallic phases formed in the Mg alloy, which keeps the degradation rate of the $\mathrm{Mg}$ alloy at a low level. Experimental results of cytotoxicity and antibacterial ability of $\mathrm{Ga}^{3+}$ and $\mathrm{Sr}^{2+}$ ions in vitro and in vivo showed that $\mathrm{Mg}$ alloys containing $\mathrm{Ga}$ and $\mathrm{Sr}$ exhibit great antibacterial ability. The results of the spread plate method indicated that the $\mathrm{Ga}-\mathrm{Mg}$ alloy can kill $90 \%$ of the bacteria whether it is for planktonic bacteria or adherent bacteria. The use of micro-alloying elements to solve clinical bone graft infection is a new strategy, but the respective roles of $\mathrm{Ga}^{3+}$ and $\mathrm{Sr}^{2+}$ in both qualitative and quantitative aspects require further work to clarify.

The above-mentioned Mg alloys have antibacterial activity to some degree, and even some of them have been successfully used [79]. But a significant issue has to be considered. Silver is not necessary for the host, and may be toxic dependent on its content [80]. Also, $\mathrm{Zn}$ and $\mathrm{Cu}$ have good antibacterial activity. However, both of them have potential toxic sequelae, regardless of their necessity for normal homeostasis.

\subsection{Antibacterial Coatings}

\subsubsection{Inorganic Antibacterial Coatings}

2.2.1.1 Metallic Oxides Coatings In addition to traditional antibacterial Mg alloys, some studies have shown that many metallic oxides also have antibacterial capabilities. For example, $\mathrm{ZnO}$ nanoparticles have been proved to produce reactive oxygen species under light and thus exhibit good antibacterial abilities [81]. CuO nanoparticles also have antibacterial capabilities, but their antibacterial mechanisms differ depending on the oxidation state. $\mathrm{CuO}$ can damage the bacterial cell walls and generate reactive oxygen, while $\mathrm{Cu}_{2} \mathrm{O}$ combines with enzymes in the bacteria to make them die [82]. $\mathrm{TiO}_{2}$ is a photocatalytic antibacterial agent. When $\mathrm{TiO}_{2}$ is irradiated with ultraviolet light, the electrons in the valence band will be excited to the conduction band and form highly active electrons. $\mathrm{O}_{2}$, which is adsorbed or dissolved on the surface of $\mathrm{TiO}_{2}$, easily captures electrons to form $\mathrm{O}_{2}^{-}[83,84]$. These free radicals with strong chemical activity can react with organic matter in various microorganisms and kill them in a short time. Ubale et al. [85] deposited nano- $\alpha-\mathrm{Fe}_{2} \mathrm{O}_{3}$ films with different thicknesses on glass substrates. Thanks to the porous nature of $\alpha-\mathrm{Fe}_{2} \mathrm{O}_{3}$, as the thickness of the film increases, more iron ions are released from the film, thereby improving the antibacterial efficiency of the film. Antibacterial experiments showed that the film thickness increased from 156 to $251 \mathrm{~nm}$, and the antibacterial efficiency of the sample increased from 37.5 to $87.5 \%$.

In our work, Cui et al. [86] prepared a $\mathrm{SnO}_{2}$-doped $\mathrm{Ca}-\mathrm{P}$ coating on the surface of $\mathrm{Mg}-1 \mathrm{Li}-1 \mathrm{Ca}$ alloy by hydrothermal technique. The antibacterial properties of the coatings were evaluated by the plate counting method. The colonyforming units (CFU) of E. coli decreased from $647 \mathrm{CFU}$ in the control group to $78 \mathrm{CFU}$ in the $\mathrm{Mg}-1 \mathrm{Li}-1 \mathrm{Ca}$ alloy to $38 \mathrm{CFU}$ in $\mathrm{SnO}_{2}$, and finally decreased to $9 \mathrm{CFU}$ in the $\mathrm{Ca}-\mathrm{P}-\mathrm{Sn}$ coated alloys.

Peng et al. [87] attached hydroxyapatite nanorods (HANRs) and $\mathrm{ZnO}$ nanorods ( $\mathrm{ZnONRs)}$ to the surface of $\mathrm{Mg}$ alloys $(\mathrm{MgA})$ by micro-arc oxidation and hydrothermal treatments. The surface of the MgA-MgO-HANRs-ZnONRs has a double-layer nano-scale structure and exhibits good hydrophilicity. In addition, the corrosion current density of $\mathrm{MgA}-\mathrm{MgO}-\mathrm{HANR}-\mathrm{ZnONRs}$ was reduced by two orders of magnitude compared with the original $\mathrm{Mg}$ alloy, showing good corrosion resistance. The results of antibacterial experiments proved that the surface has excellent antibacterial properties; and the sterilization rates of $E$. coli and $S$. aureus reached $94.3 \%$ and $96.5 \%$, respectively.

2.2.1.2 Diamond-Like Carbon (DLC) Diamond-like carbon (DLC) is a metastable amorphous carbon with a large amount of sp3 bonds. Its films combine several excellent properties like high hardness, low friction coefficients and chemical inertness [88]. DLC coating could enhance the antibacterial effect of Mg-based alloys, while conventional DLC coatings do not adhere well to Mg-based materials because of the large internal stress from $s p 3$ bonds. Plasma immersion ion implantation and deposition (PIII\&D) has been proved to increase the bonding strength. Therefore, many studies have utilized PIII\&D to prepare DLC coatings to enhance substrate corrosion resistance $[89,90]$.

In recent years, studies have shown that DLC coatings also have antibacterial capabilities. Jin et al. [91] produced a DLC coating on Mg alloy AZ31 through PIII\&D and evaluated its antibacterial properties. The results showed that the number of bacteria on AZ31 was reduced to $5 \times 10^{4} \mathrm{CFU}$ after $6 \mathrm{~h}$, while there were no live bacteria on AZ31 coated with DLC. Feng et al. [92] also used PIII\&D to deposit DLC coating on AZ31 Mg alloy. The antibacterial experiment showed that the starting bacteria number of the samples AZ31 and AZ31-DLC were about $3 \times 10^{4} \mathrm{CFU}$.

After $3 \mathrm{~h}$, the number of bacteria on AZ31-DLC was reduced to $2.3 \times 10^{2} \mathrm{CFU}$, while the number of bacteria on sample AZ31 hardly changed. There were no viable bacteria on AZ31-DLC after $6 \mathrm{~h}$, while the number of bacteria on AZ31 was reduced to $5 \times 10^{3} \mathrm{CFU}$. The antibacterial mechanism of the DLC coating may be the ability of the DLC film to adsorb bacteria, resulting in bacteria being threatened by higher concentrations of $\mathrm{Mg}^{2+}$ and $\mathrm{OH}^{-}$.

2.2.1.3 Graphene Graphene, a $\mathrm{sp}^{2}$ hybrid two-dimensional single-layer carbon atom sheet, has attracted extensive research interest in recent years [93]. Graphene and its derivatives not only have excellent physical and chemi- 
cal properties, such as large specific surface area [94], excellent thermal conductivity [95], high Young's modulus [96], etc., but also have good antibacterial capabilities.

Qiu et al. [97] investigated the changes in the antibacterial activity of graphene and its derivatives with various factors, such as size, number of layers, oxygen-containing groups, and experimental environment. The final results showed that graphene oxide deposited by electrophoresis showed the best antibacterial activity against $S$. aureus. Hamzah et al. [98] deposited a new type of nano-silica $\left(\mathrm{SiO}_{2}\right) /$ graphene oxide (GO) coating on $\mathrm{Mg}$ alloy by a combination of physical vapor deposition (PVD) and immersion coating. The bottom layer of nano- $\mathrm{SiO}_{2}$ has a dense columnar structure, while the GO layer has a lamellar shape. Antibacterial experiments showed that the $\mathrm{SiO}_{2} /$ GO coating exhibits strong antibacterial activity against streptococcus, and the coating's corrosion resistance is also significantly improved. El-Kamel et al. [99] prepared GO nanoparticles/polythreonine polymer nano-coatings on AZ91E Mg alloy. This novel coating is degradable and has good biological activity. The antibacterial properties of the coating were evaluated by the size of the bacteriostatic area. The results showed that the antibacterial circle radius $(18 \mathrm{~mm})$ of the coated $\mathrm{Mg}$ alloy is larger than that $(12 \mathrm{~mm})$ of the uncoated, indicating that the coating has certain antibacterial properties. This GO nanoparticles coating is also expected to be a new temporary implant for gastrectomy.

Although there are many antibacterial applications of graphene, the specific antibacterial mechanism is still controversial. The currently proposed mechanisms are as follows: nanoknife, oxidative stress, encapsulation or capture [100]. At the same time, the physical and chemical properties of graphene will also affect its antibacterial activity. Its size [101], number of sheets, and surface functions will affect bacterial interactions [102]. In short, the antibacterial mechanism of graphene needs further research, but with the advancement of technology, humans will eventually solve it and apply it to the biological or medical field.

\subsubsection{Organic Antibacterial Coating}

The use of organic polymer to modify the surface of $\mathrm{Mg}$ alloys has the advantages of simple process and good corrosion resistance, and can control polymer groups to achieve better biocompatibility. Polymer materials such as polylactic acid [103], polyglycolide [104], chitosan (CS) [105] that have good biocompatibility and degradability are ideal organic coating materials. Implantable organic polymer coatings are widely recognized as a viable method for controlling and directing cellular responses such as adhesion, proliferation and differentiation [106].
2.2.2.1 Chitosan Chitosan is a linear macromolecular polysaccharide obtained by deacetylation of chitin, and the second most abundant biopolymer after cellulose [107]. Early research has shown that CS and its derivatives exhibit antibacterial activity against fungi [108], bacteria [109], and viruses [110]. The antibacterial mechanism of CS involves electrostatic interactions, plasma membrane damage, interactions with DNA/RNA, metal chelation on chitosan and deposition of microbial surfaces [111].

Wang et al. [112] carried out a mussel-inspired nanomultilayered coating through PDA and CS assisted layerby-layer (LbL) assembly of biomimetic carbonated apatite (CAp) and sliver nanoparticles on AZ31 alloy. Due to the excellent antibacterial properties of Ag nanoparticles, good osteoinduction of CAp [113] and biodegradability of CS, the coating not only acts as a protective layer for the substrate, but also shows good biological performance. It is reported that the bacteria can complete the initial adhesion within $4 \mathrm{~h}$ and then form a biofilm to cause infection [114, 115]. Therefore, the initial antibacterial performance of the $\mathrm{Mg}$ alloy surface coating is of great importance. The bacteria used in antibacterial experiments are S. aureus and E. coli, which are typical Gram-positive and Gram-negative bacteria, respectively. The results showed that the antibacterial rate of the outermost coatings with Ag@PDA against $E$. coli and $S$. aureus was $94 \%$ and $83.3 \%$ after $4 \mathrm{~h}$. After $4 \mathrm{~h}$, the antibacterial rates of AZ31 coated with CAp@PDA as the outermost layer against E. coli and $S$. aureus reached 83.3\% and $91 \%$, both exhibited good antibacterial properties. And such coating overcomes the conflicts between antibacterial property and biocompatibility, and provides deep insights into surface versatile functionalization.

Cui et al. [116] produced a coating on AZ31 Mg alloy by LbL assembly of CS and poly-L-glutamic acid (PGA). The antibacterial properties of the samples against $S$. aureus were evaluated by the zone of plate-counting method, whose result shows that the obtained coating reduced the number of bacteria from $411 \pm 17 \mathrm{CFU}$ on bare AZ31 alloy to $11 \pm 2 \mathrm{CFU}$. The main reason may be ascribed to the contact of the coating surface with bacteria, which directly leads to the death of bacteria [117].

2.2.2.2 Polyurethane Polyurethane (PU) has controllable molecular structure and properties and is widely used in various industries. In the field of biomedicine, PU is considered as a promising surface coating material because of its good biocompatibility and biodegradability [118]. Wang et al. [119] first synthesized polyethylene glycol (PEG) chains and zwitterions (ZPU)-functionalized PU and then applied them to the coating of Mg-based rods. The antibacterial properties of PU come from the hydration barrier formed by these PEG chains or ZPU groups. Therefore, they used $E$. coli and $P$. aeruginosa to evaluate the antibacterial 
adhesion properties of PU samples. The results showed that the number of bacterial cells absorbed on the GPU and ZPU surfaces is much lower than that absorbed on the PU surface, which indicates that functionalized PU exhibits good anti-adhesive effects on bacteria.

2.2.2.3 Antibiotics Antibiotics are also used in the preparation of antibacterial coatings due to their excellent antibacterial properties. The antibacterial coatings prepared by typical antibiotics on the surface of $\mathrm{Mg}$ alloys are summarized in Table 2. Common antibiotics are levofloxacin [120], tetracycline [121, 122], penicillin, etc. Gentamicin sulfate (GS) is an antibiotic widely used to prevent implant-related infections [123]. Ji et al. [124] prepared a novel GS-induced HAp coating on the surface of AZ31 Mg alloy by LbL assembly method. The antibacterial property of the pattern was evaluated by counting the number of colonies on the sample. The sample containing gentamicin sulfate had a surface bacteria number of $1 \pm 1 \mathrm{CFU}$, which was less than $538 \pm 16 \mathrm{CFU}$ of AZ31 and $1659 \pm 24 \mathrm{CFU}$ of pure HAp.

A study by Ji et al. [125] successfully prepared a ciprofloxacin (CIP)-loaded polymer multilayer film-induced HAp coating on the surface of AZ31 Mg alloy by dip-LbL technique and hydrothermal treatment. The coating's dense sheet morphology and high crystalline apatite structure exhibit great corrosion resistance. Furthermore, the CIP-loaded coating has antibacterial properties against $E$. coli and $S$. aureus [126], probably because the dense coating extends the path of antibiotic release, and the CIP-coated coating exhibits longer-lasting drug release characteristics, which helps to enhance the long-term antimicrobial behavior of Mg alloys.

2.2.2.4 Peptides Antimicrobial peptides (AMPs) are an important part of the natural defense of most organisms [127]. These peptides are broad-spectrum resistant to both Gram-positive and Gram-negative bacteria [128]. In addition, a variety of human proteins and peptides also have antibacterial activity and play an important role in the immune system.

At present, there are few studies on the surface modification of $\mathrm{Mg}$ alloys using peptides, but Chen et al. [129] have successfully prepared antibacterial peptide coatings on the surface of titanium alloys. They have designed Anchor-AMP which can be directly assembled on the surface of biomaterials. Antibacterial experiments showed that Anchor-AMP performed excellent antibacterial activity on the titanium surface and inhibited $95.33 \%$ of E. coli and $96.67 \%$ of $S$. aureus after $2.5 \mathrm{~h}$. In addition, in vivo antibacterial results showed that Anchor-AMP still exhibited a high inhibitory effect on bacteria after 5 and 7 days, respectively, inhibiting $89.32 \%$ and $99.78 \%$ of $S$. aureus.

Anchor-AMP can be easily and directly assembled to the surface of the material, and exhibits excellent antibacterial properties in vivo and in vitro, which provides an idea for the surface modification of biomedical Mg alloys. Based on the advances in coatings preparation of biodegradable $\mathrm{Mg}$ alloys [130], it is promising to apply antimicrobial peptides to prepare antibacterial surfaces of $\mathrm{Mg}$ alloys in the future.

2.2.2.5 Tannic Acid Tannic acid (TA) is a water-soluble polyphenol compound that can be extracted from fruits such as grapes, and also from daily drinks such as tea or red wine [131]. Because of its polyphenol structure, TA also has antibacterial properties. The antibacterial mechanism of TA may be their o-diphenol group enabling them to act as iron chelator, thus depriving microorganisms of essential elements for life activities [132]. The hydroxyl group of TA also has the ability to penetrate the bacterial cell wall, thereby destroying the cytoplasmic membrane, increasing the permeability of the cell membrane, and changing the ratio of protein to lipid in the membrane [133,134].

In our previous research, Cui et al. [135] prepared a micro-arc oxidation (MAO) coating with phytic acid (PA) and TA on the AZ31 Mg alloy. The coating exhibits good corrosion resistance and antibacterial properties, and in particular exhibits good biomimetic mineralization effects,
Table 2 Summary of antibiotic coating on $\mathrm{Mg}$ alloys

\begin{tabular}{llllll}
\hline Antibiotic & Substrate & Bacterial & Method & Coating & Refs. \\
\hline GS & AZ31 & S. aureus & Dipping & (PAA/GS) $)_{20}$ (PAA-HAp & {$[124]$} \\
GS & AZ31 & S. aureus & Dipping & $(\text { PSS/GS })_{20}$, PSS/GS $)_{60}$ & {$[148]$} \\
CIP & AZ31 & S. aureus/E. coli & Dipping/hydrothermal & $(\text { CIP/PAH })_{10} /$ CIP-HAp & {$[125]$} \\
Lev & AZ31 & S. epidermidis & Dipping & (PLGA-PCL)-Lev, HAp & {$[120]$} \\
TC & AZ91D & S. aureus & Dipping & CaP-TC & {$[121]$} \\
TC & Mg-6\%Zn & E. coli/S. aureus & Dipping & MZ-TC & {$[122]$} \\
Van & AZ31D & E. coli & MAO/sol-gel & MAO/SA-Van & {$[159]$} \\
\hline
\end{tabular}

$G S$ gentamicin sulfate, $P A A$ polyacrylic acid, $P S S$ sodium 4-styrene sulfonate, $C I P$ ciprofloxacin, $P A H$ poly (allylamine hydrochloride), HAp hydroxyapatite, Lev levofloxacin, PLGA poly(lactic-co-glycolic) acid, $P C L$ polycaprolactone, $T C$ tetracycline, Van vancomycin, $S A$ sodium alginate 
which helps to promote faster recovery and reduce medical burden on patients. The antibacterial mechanism of the coating is mainly attributed to the antibacterial effect of TA. On the one hand, the polyphenolic group of TA destroys the stability and integrity of the bacterial cell wall and cell membrane [136]. On the other hand, TA can chelate the metal ions to reduce the activity of metalloenzymes, which are essential for bacterial growth [137].

\section{Methods for Preparing Antibacterial Coating}

Preparation of a suitable coating on the surface of Mg alloys by surface modification is an effective way to improve the antibacterial properties of biomedical $\mathrm{Mg}$ alloys [138]. The adoption of suitable surface modification technology can not only preserve the excellent properties of the biomedical materials, but also prepare needed material surface according to different clinical applications $[139,140]$.

\subsection{Physical Antibacterial Methods}

One strategy is to achieve the antibacterial purpose by constructing a bionic surface without using antibacterial agent. This process can also be called physical antibacterial. The idea is mainly derived from the antibacterial effect of sharkskin, which builds a surface similar to shark skin to inhibit the initial adhesion of bacteria. Brennan et al. [141] designed a surface microtopography based on shark skin on poly(dimethylsiloxane) elastomer (PDMSe) Sharklet AFTM. They tested the effect of the surface on $S$. aureus film formation, and the results showed that there was no evidence of early biofilms colonization until day 21 , suggesting that the surface could disrupt the formation of bacterial biofilms without using bactericide. A study performed by Miyazaki et al. [142] also focused on the antibacterial properties of shark skins. They prepared the surface of shark-like skin by nanoimprinting and evaluated the antibacterial properties of the samples by bacterial coverage. The results show that in the circulating state, the surface of the sample will have a longitudinal vortex effect so that the bacteria attached to the surface will be removed, and the coverage of the bacteria will be reduced. Sharklet micropatterns have been used to inhibit the colonization and migration of common urinary tract pathogens [143]. This process achieves this performance only through physical surface modification without the use of any antimicrobials.

\subsection{Doped with Antibacterial Agent}

Another antibacterial surface preparation idea is to prepare a coating containing antibacterial agents or integrate them into $\mathrm{Mg}$ alloy, and achieve the antibacterial purpose through the release of the antibacterial agent. The common methods are as follows.

\subsubsection{Layer-by-Layer Assembly}

A large amount of antibacterial coatings is prepared using LbL assembly techniques. LbL assembly technology is a multifunctional coating technology first proposed by Decher et al. in 1992 [144]. This method is completed by alternately depositing oppositely charged polyelectrolytes on the surface of a charged substrate. The function of the LbL film is determined by the deposited components, and the thickness of the film depends on the number of assembled [145]. $\mathrm{LbL}$ assembly can infiltrate bactericidal ingredients such as metal ions or antibiotics into the multilayer film system, and adjust the strength of the interaction between the components according to actual needs. This allows the antibacterial ingredient to be released into the human environment or to stay firmly on the surface of the substrate to kill the bacteria when in contact.

Zhao et al. [146] prepared polymethyltrimethoxysilane (PMTMS)-silver nanoparticle coatings on the surface of AZ31 Mg alloy by LbL assembly. When the number of assembling layers is 5, the coating's bacteriostatic rate against $S$. aureus reaches $85 \%$, showing good antibacterial properties. Cui et al. [147] carried out a polyvinylpyrrolidone (PVP)/deoxyribonucleic acid (DNA) coating by LbL assembly, which reduced the self-corrosion current density of the $\mathrm{Mg}$ alloy by an order of magnitude, indicating its good corrosion resistance. Liu et al. [148] prepared polyelectrolyte and polysiloxane coatings on the surface of AZ31 Mg alloy by LbL assembly. The composite coating significantly improved the corrosion resistance of the Mg alloy. In addition, the number of bacteria on the surface of the sample was reduced by $99 \%$ after $2 \mathrm{~h}$ of incubation, which means its good antibacterial performance.

\subsubsection{Micro-arc Oxidation with $\mathrm{Ag}, \mathrm{Cu}, \mathrm{Zn}$}

Micro-arc oxidation (MAO), also known as plasma oxidation, is a technology that produces a ceramic oxide coating with high bonding strength, which can grow in situ on the $\mathrm{Mg}$ substrate, and can improve the wear resistance, corrosion resistance, heat resistance, and electrical insulation of the $\mathrm{Mg}$ alloys [149]. Coating formed by MAO shows many pores and cracks, which is a, respectively, loose layer. Ren et al. [150] prepared the silicon coating on the surface of pure Mg by MAO and compared it with the silicon coating prepared by chemical conversion. The results showed that due to the loose and porous structure of the MAO coating, the Mg substrate had many channels of contact with the physiological solution, which allowed $\mathrm{Mg}$ to exert its 
antibacterial properties when exposed to the physiological solution. The main antimicrobial mechanism may be that degradation of the $\mathrm{Mg}$ substrate raises the $\mathrm{pH}$ of the solution, making it impossible for bacteria to survive normally in a $\mathrm{pH}$ range (6.0-8.0) that maintains their cytoplasmic structure and function [151]. For Mg alloy, single MAO has no antibacterial effect. Therefore, antibacterial elements are added in the process of MAO to improve the antibacterial properties of $\mathrm{Mg}$ alloy.

Yan et al. [61] used a solution treatment method for $\mathrm{Mg}-0.06 \mathrm{Cu}$ and prepared MAO coating on its surface. The antibacterial experiment result shows that the antibacterial efficacy (ABE) of as-solution alloy was higher than that of the pure $\mathrm{Mg}$, which indicates that the releasing of $\mathrm{Cu}^{2+}$ ions was effective for antimicrobial use. The main sterilization mechanism may be the increase in $\mathrm{Cu}^{2+}$ and $\mathrm{OH}^{-}$concentration caused by $\mathrm{Mg}-0.06 \mathrm{Cu}$ degradation [152]. In general, the addition of impurity elements such as $\mathrm{Cu}$ may reduce the corrosion resistance of $\mathrm{Mg}$ alloys. However, in this study, only a small amount of $\mathrm{Cu}$ was added and the surface treatment of Mg alloy was performed by MAO. These two processes can be seen as mutually restrictive effects, jointly determining the properties of the alloy. In addition to exhibiting great antibacterial properties, the biodegradability and biocompatibility of $\mathrm{Mg}-0.06 \mathrm{Cu}$ have also been improved.

Mehmet et al. [153] performed a MAO treatment on the surface of the $\mathrm{Mg}-\mathrm{Sr}-\mathrm{Ca}$ ternary alloy. Note that, in order to improve the antibacterial property of the material, they added Ag-Hap nano-powder to the MAO solution. Chen et al. [138] systematically studied the structure of MAO coating containing $\mathrm{Cu}$ on $\mathrm{Mg}-2 \mathrm{Zn}-1 \mathrm{Gd}-0.5 \mathrm{Zr}$ alloy by combining the good antibacterial property of $\mathrm{Cu}$ with the good corrosion resistance of MAO coating. The results revealed that the addition of $\mathrm{Cu}$ could further improve the degradation resistance of MAO-coated alloy, and the antibacterial rate reaches $96 \%$.

\subsubsection{Chemical Conversion}

Chemical conversion is a low-cost and simple surface modification technology. Conversion coating is usually formed by the reaction between the solution and the substrate. The bonds between them are chemical bond, so the adhesion between the coating and the substrate is very strong. Chromate conversion is a relatively mature chemical conversion method [154]; however, the introduction of $\mathrm{Cr}^{6+}$ ion is toxic [155], which is not conducive to the clinical application of biomedical Mg alloy. Calcium phosphate coatings are of special interest for biomedical application in bone substitution and orthopedic materials, due to their superior biocompatibility, high osteoconductivity, and low toxicity in the physiological environment. However, the formation of bacterial biofilm on the surface of HAp may cause serious infection [156]. Therefore, several studies have been carried out to improve the antibacterial properties of calcium phosphorus layers.

Yan et al. [157] studied a fluoride conversion coating, which was prepared on AZ31B Mg alloy by chemical reaction in hydrofluoric acid. The X-ray diffraction analysis indicated that the coating was mainly composed of $\mathrm{MgO}$ and $\mathrm{MgF}_{2}$. The antibacterial rate of fluoride-coated AZ31B samples exceeds $99.99 \%$, while that of the control 316L stainless steel was $0 \%$, indicating that the fluoride conversion film could provide excellent antibacterial surface for AZ31B. Hu et al. [158] carried out a Ag/HAp composite coating via chemical conversion process on an extruded $\mathrm{Mg}-2 \mathrm{Zn}-1 \mathrm{Mn}-0.5 \mathrm{Ca} \mathrm{Mg}$ alloy. Due to the release of $\mathrm{Ag}$ particles from the $\mathrm{Ag} / \mathrm{HAp}$ composite coating, the $\mathrm{Mg}$ alloy samples showed good inhibition against $S$. aureus. Its bacteriostatic circle is about $14 \mathrm{~mm}$ in diameter.

\subsubsection{Sol-Gel}

The sol-gel method with the advantages of high purity and good uniformity is also an effective method for preparing films and coating materials. Du et al. [159] utilize the electrostatic interaction between polyethyleneimines to prepare vanamycin (Van)-loaded sodium alginate (SA) hydrogel coatings on the surface of Mg alloys treated with MAO. Due to the bactericidal ability of vancomycin, the MgA/MAO/SA-Van coating showed a significant area of inhibition against $S$. aureus and $E$. coli, indicating that the sample has good antibacterial activity.

\subsubsection{Ion Implantation}

Ion implantation uses the action of a high-voltage electric field to ionize element atoms prepared in advance into ions and inject them into the surface of $\mathrm{Mg}$ alloys. For implants, this method can handle irregular samples and is an effective way to improve the surface properties of materials. Cheng et al. [160] successfully implanted $\mathrm{Zr}$ and $\mathrm{N}$ ions into the AZ91 Mg alloy and formed a modified layer with a thickness of about $80 \mathrm{~nm}$ on the surface of the $\mathrm{Mg}$ alloy. Corrosion resistance test, antibacterial test and cell compatibility test results revealed that the dual-ion implantation of $\mathrm{Zr}$ and $\mathrm{N}$ not only enhanced the corrosion resistance of AZ91 Mg alloy but also provided better antibacterial properties. The possible antibacterial mechanism is that $\mathrm{ZrO}_{2}$ and $\mathrm{ZrN}$ are generated on the surface of the $\mathrm{Mg}$ alloy, which makes it more hydrophobic and inhibits initial bacterial adhesion [161]. 


\section{Challenges of Biodegradable Mg Alloys in the Biomedical Field}

\subsection{Biocompatibility}

Although the addition of antibacterial agents can improve the antibacterial performance of $\mathrm{Mg}$ alloys, it is essential that biomedical implants should control the release of metal ions below a threshold level. Under normal circumstances, the concentration of toxic element ions released in the human body is extremely low and can be tolerated below its threshold level, while excessive release in the body will endanger human health [162]. Studies have summarized the toxic dose of metal ions at $50 \%$ cell survival rate (TD50) of bone-related cells (MC3T3E1 and MG63 cell lines) [163]. $\mathrm{Mg}$ is a mildly toxic element, while $\mathrm{Ag}$, $\mathrm{Cu}$, and $\mathrm{Zn}$ are severely toxic elements. Therefore, special attention should be paid to their biocompatibility when using these metal ion antibacterial agents. The usual strategy is to deposit a polymer coating on the surface of the $\mathrm{Mg}$ alloy to form a composite antibacterial coating [164], thereby promoting the controlled exposure of these metal ions in the body and improving biocompatibility.

\subsection{Corrosion Resistance}

Under the physiological environment of chloride ion in the human body, $\mathrm{Mg}$ alloys will rapidly corrode and degrade, continue to produce hydrogen gas, produce large toxic and side effects to the human body, and cause inflammation of surrounding tissues [165]. Some $\mathrm{Mg}$ alloys containing antibacterial elements use the biodegradability of $\mathrm{Mg}$ alloys to release antibacterial metal ions for sterilization. However, high degradation rate cannot well match tissue repair process and may result in severe cytotoxicity [166]. Therefore, it is meaningful to combine the corrosion resistance and antibacterial properties of biodegradable Mg alloys. The specific test methods most commonly used were immersion tests, polarization studies and impedance spectroscopy. Since the degradation rate of $\mathrm{Mg}$ alloy is too fast, we usually hope to improve its corrosion resistance so that it can work longer. But that does not mean we want them to be permanent implants. In many cases, the body needs only the temporary presence of an implant or device, in which case materials exhibiting biodegradability represent a better approach than stable and inert ones. Researchers hope to control the degradation rate of $\mathrm{Mg}$ alloys within a certain range, making them comparable to tissue or bone healing. Such slow degradation not only releases antibacterial substances for a long period of time, but also produces $\mathrm{Mg}$ ions that promote bone growth without compromising health [167].

\subsection{Long-Term Antibacterial Behavior}

Drug delivery system with extended drug release profile is an effective means for long-term treatment of bacterial infections. For coatings containing metal ion antibacterial agents, too fast release of the antibacterial agent will not only produce greater toxicity but also greatly shorten the life of the implant. Although antibiotics have significant effects, they are highly irritating and prone to allergic reactions. Therefore, researchers usually prepare porous morphologies on the surface of $\mathrm{Mg}$ alloys or use zeolites, montmorillonite and other materials to carry drugs to control the release rate. Another strategy is to wrap the drug with a milder substance, forming a "capsule". Dong et al. [168] used electrospinning to prepare gelatinciprofloxacin (Gel-Cip) nanofibers on the surface of $\mathrm{Mg}-\mathrm{Ca}$ alloy. The coating obtained a longer drug release time and had no inhibitory influence on cell compatibility.

In addition to the above-mentioned performance needs to be considered, the impact of Mg alloys on patient recovery speed should also be paid attention to. The ideal implant should have the ability to promote bone healing, prevent bacterial adhesion and minimize prosthetic infection [169]. However, some biomaterials with anti-adhesion properties have a strong inhibitory effect on the adhesion of bacteria to the implant surface, which will slow down the rate of tissue integration, thereby increasing the patient's recovery cycle and increasing the risk of long-term infection [170]. But the biggest challenge is the release mechanism of antibacterial agents: passive release. This prevents the antibacterial agent from remaining in the biomaterial system for a sufficient period of time after the implant enters the body. However, with the development of new materials and technologies, the Lewis team discovered a new antibiotic, Darobactin [171]. It can bind to the key outer membrane proteins of bacteria, destroy the outer membrane of bacteria and induce cell lysis. This specific bactericidal mechanism will also bring new ideas and inspiration to the development and application of antibacterial biomaterials.

\section{Conclusions and Outlooks}

This review focuses on the various antibacterial layers and antibacterial mechanisms prepared on $\mathrm{Mg}$ alloys by different methods. Existing antibacterial strategies are mainly by adding antibacterial agents to the surface of $\mathrm{Mg}$ alloys to inhibit the colonization and reproduction of bacteria, thereby reducing the probability of infection and the risk of implant failure. In addition, achieving the antibacterial properties of $\mathrm{Mg}$ alloys is not limited to chemically based bactericidal methods. Physical antibacterial methods may also work in this regard by constructing bionic superhydrophobic or superslip surfaces. This process inhibits the initial adhesion of bacteria and can effectively prevent the formation of biofilms. In the future, this method of 
achieving antibacterial properties of materials without adding antibacterial agents may attract more attention. In the long run, the development and design of $\mathrm{Mg}$ alloy biomedical applications cannot be limited to antibacterial properties. Its corrosion resistance, biocompatibility, drug release cycle and so on all need systematic research. More consideration should be given to the role of surface topography in the formation of antibacterial or antifouling surfaces, especially at the nanoscale.

Acknowledgements This work was supported by the National Natural Science Foundation of China (No. 51571134) and the Shandong University of Science and Technology Research Fund (No. 2014TDJH104).

\section{References}

[1] Q.Z. Chen, G.A. Thouas, Mater. Sci. Eng. R 87, 1 (2015)

[2] E. Schacht, Biomaterials (2004).

[3] M. Moravej, D. Mantovani, Int. J. Mol. Sci. 12, 4250 (2011)

[4] Y.J. Chen, Z.G. Xu, C. Smith, J. Sankar, Acta Biomater. 10, 4561 (2014)

[5] D.A. Puleo, W.W. Huh, J. Appl. Biomater. 6, 109 (1995)

[6] A. Chaya, S. Yoshizawa, K. Verdelis, N. Myers, B.J. Costello, D.T. Chou, S. Pal, S. Maiti, P.N. Kumta, C. Sfeir, Acta Biomater. 18, 262 (2015)

[7] J.J. Jacobs, J.L. Gilbert, R.M. Urban, J. Bone Jt. Surg. 80, 268 (1998)

[8] H.X. Wang, S.K. Guan, Y.S. Wang, H.J. Liu, H.T. Wang, L.G. Wang, C.X. Ren, S.J. Zhu, K.S. Chen, Colloids Surf. B 88, 254 (2011)

[9] A. Łyskowski, J.C. Leo, A. Goldman, Adv. Exp. Med. Biol. 715, 143 (2011)

[10] M.S. Song, R.C. Zeng, Y.F. Ding, R.W. Li, M. Easton, I. Cole, N. Birbilis, X.B. Chen, J. Mater. Sci. Technol. 35, 535 (2019)

[11] R.M. Donlan, Emerging. Infect. Dis. 8, 881 (2002)

[12] S. Aiola, G. Amico, P. Battaglia, E. Battistelli, Clin. Microbiol. Rev. 15, 167 (2002)

[13] J.W. Costerton, P.S. Stewart, E.P. Greenberg, Science 284, 1318 (1999)

[14] A. Agarwal, K.P. Singh, A. Jain, F.E.M.S. Immunol, Med. Microbiol. 58, 147 (2010)

[15] M. Chicurel, Nature 408, 284 (2000)

[16] A.F. Mendonca, T.L. Amoroso, S.J. Knabel, Appl. Environ. Microbiol. 60, 4009 (1994)

[17] A. Singh, A.K. Dubey, A.C.S. Appl, Bio Mater. 1, 3 (2018)

[18] M.P. Staiger, A.M. Pietak, J. Huadmai, G. Dias, Biomaterials 27, 1728 (2006)

[19] H.X. Wang, S.J. Zhu, L.G. Wang, Y.S. Feng, X. Ma, S.K. Guan, Appl. Surf. Sci. 307, 92 (2014)

[20] L.Y. Li, L.Y. Cui, R.C. Zeng, S.Q. Li, X.B. Chen, Y. Zheng, M.B. Kannan, Acta Biomater. 79, 23 (2018)

[21] M.I. Rahim, M. Rohde, B. Rais, J.M. Seitz, P.P. Mueller, J. Biomed. Mater. Res. A 104, 1489 (2016)

[22] H.Q. Feng, G.M. Wang, W.H. Jin, X.M. Zhang, Y.F. Huang, A. Gao, H. Wu, G.S. Wu, P.K. Chu, A.C.S. Appl, Mater. Interfaces 8, 9662 (2016)

[23] D.A. Robinson, R.W. Griffith, D. Shechtman, R.B. Evans, M.G. Conzemius, Acta Biomater. 6, 1869 (2010)

[24] J. Rodríguez-Sánchez, M.Á. Pacha-Olivenza, M.L. GonzálezMartín, Mater. Chem. Phys. 221, 342 (2019)

[25] A.A. Yates, S.A. Schlicker, C.W. Suitor, J. Am. Diet. Assoc. 98, 699 (1998)

[26] F. Witte, J. Fischer, J. Nellesen, H.A. Crostack, V. Kaese, A. Pisch, F. Beckmann, H. Windhagen, Biomaterials 27, 1013 (2006)
[27] X.J. Wang, D.K. Xu, R.Z. Wu, X.B. Chen, Q.M. Peng, L. Jin, Y.C. Xin, Z.Q. Zhang, Y. Liu, X.H. Chen, G. Chen, K.K. Deng, H.Y. Wang, J. Mater. Sci. Technol. 34, 245 (2018)

[28] A.R. Shahverdi, A. Fakhimi, H.R. Shahverdi, S. Minaian, Nanomed. Nanotechnol. Biol. Med. 3, 168 (2007)

[29] R. Torrecillas, M. Díaz, F. Barba, M. Miranda, F. Guitián, J.S. Moya, J. Nanomater. 2009, 1 (2009)

[30] R. Grosjean, S. Delacroix, G. Gouget, P. Beaunier, O. Ersen, D. Ihiawakrim, O. Kurakevych, D. Portehault, Dalton Trans. 47, 7634 (2017)

[31] S.J. Fang, Y.H. Liu, L.H. Diao, S.R. Yu, J. Zhang, ISIJ Int. 47, 1647 (2007)

[32] J. Xia, D.K. Xu, L. Nan, H.F. Liu, Q. Li, K. Yang, Chin. J. Mater. Res. 30, 161 (2016)

[33] K. Pradeev Raj, K. Sadaiyandi, A. Kennedy, S. Sagadevan, J. Mater. Sci. Mater. Electron. 28, 19025 (2017)

[34] S. Medici, M. Peana, V.M. Nurchi, M.A. Zoroddu, J. Med. Chem. 62, 5923 (2019)

[35] K. Mijnendonckx, N. Leys, J. Mahillon, S. Silver, R. Van Houdt, Biometals 26, 609 (2013)

[36] J. Alexander, Wesley. Surg. Infect. 10, 289 (2009)

[37] M. López-Heras, I.G. Theodorou, B.F. Leo, M.P. Ryan, A.E. Porter, Environ. Sci NANO 2, 312 (2015)

[38] X. Yuan, M.I. Setyawati, D.T. Leong, J.P. Xie, Nano Res. 7, 301 (2014)

[39] J.A. Spadaro, T.J. Berger, S.D. Barranco, S.E. Chapin, R.O. Becker, Antimicrob. Agents Chemother. 6, 637 (1974)

[40] A. Gupta, K. Matsui, J.F. Lo, S. Silver, Nat. Med. 5, 183 (1999)

[41] O. Choi, K.K. Deng, N.J. Kim, L. Ross, R.Y. Surampalli, Z. Hu, Water Res. 42, 3066 (2008)

[42] Q.L. Feng, J. Wu, G.Q. Chen, F.Z. Cui, T.N. Kim, J.O. Kim, J. Biomed. Mater. Res. 52, 662 (2000)

[43] A. Mocanu, G. Furtos, S. Rapuntean, O. Horovitz, C. Flore, C. Garbo, A. Danisteanu, G. Rapuntean, C. Prejmerean, M. Tomoaia-Cotisel, Appl. Surf. Sci. 298, 225 (2014)

[44] D. Tie, F. Feyerabend, W.D. Müller, R. Schade, K. Liefeith, K. Kainer, R. Willumeit, Eur. Cells Mater. 25, 284 (2013)

[45] Q.M. Peng, K. Li, Z.S. Han, E. Wang, Z.G. Xu, R.P. Liu, Y.J. Tian, J. Biomed. Mater. Res. A 101, 1898 (2013)

[46] K. Chamakura, R. Perez-Ballestero, Z. Luo, S. Bashir, J. Liu, Colloids Surf. B 84, 88 (2011)

[47] I. Sondi, B. Salopek-Sondi, J. Colloid Interface Sci. 275, 177 (2004)

[48] R.C. Zeng, L.J. Liu, S.Q. Li, Y.H. Zou, F. Zhang, Y.N. Yang, H.Z. Cui, E.H. Han, Acta Metall. Sin. -Engl. Lett. 26, 681 (2013)

[49] J. Song, H. Kang, C. Lee, S.H. Hwang, J. Jang, A.C.S. Appl, Mater. Interfaces 4, 460 (2012)

[50] P. Szymański, T. Fraczek, M. Markowicz, E. Mikiciuk-Olasik, Biometals 25, 1089 (2012)

[51] L.N. Mukerjee, S.N. Srivastava, Kolloid-Z. 150, 148 (1957)

[52] G. Grass, C. Rensing, M. Solioz, Appl. Environ. Microbiol. 77, 1541 (2011)

[53] L. Nan, D.K. Xu, T.Y. Gu, X. Song, K. Yang, Mater. Sci. Eng. C 48, 228 (2015)

[54] L. Nan, K. Yang, J. Mater. Sci. Technol. 26, 941 (2010)

[55] I. Burghardt, F. Lüthen, C. Prinz, B. Kreikemeyer, C. Zietz, H.G. Neumann, J. Rychly, Biomaterials 44, 36 (2015)

[56] L. Nan, W.C. Yang, Y.Q. Liu, H. Xu, Y. Li, M.Q. Lu, K. Yang, J. Mater. Sci. Technol. 24, 197 (2008)

[57] D.A. Cooksey, F.E.M.S. Microbiol, Rev. 14, 381 (1994)

[58] C. Liu, X.K. Fu, H.B. Pan, P. Wan, L. Wang, L.L. Tan, K.H. Wang, Y. Zhao, K. Yang, P.K. Chu, Sci. Rep. 6, 1 (2016)

[59] K.D. Cashman, A. Baker, F. Ginty, A. Flynn, J.J. Strain, M.P. Bonham, J.M. O'Connor, S. Bügel, B. Sandström, Eur. J. Clin. Nutr. 55, 525 (2001)

[60] Y. Li, L.N. Liu, P. Wan, Z.J. Zhai, Z.Y. Mao, Z.X. Ouyang, D.G. Yu, Q. Sun, L.L. Tan, L. Ren, Z.N. Zhu, Y.Q. Hao, X.H. Qu, K. Yang, K.R. Dai, Biomaterials 106, 250 (2016) 
[61] X.D. Yan, M.C. Zhao, Y. Yang, L.L. Tan, Y.C. Zhao, D.F. Yin, K. Yang, A. Atrens, Corros. Sci. 156, 125 (2019)

[62] R. Xu, M.C. Zhao, Y.C. Zhao, L. Liu, C. Liu, C. Gao, C. Shuai, A. Atrens, Mater. Lett. 237, 253 (2019)

[63] Y. Li, W. Xiong, C.C. Zhang, B. Gao, H.F. Guan, H. Cheng, J.J. Fu, F. Li, J. Biomed. Mater. Res. A 102, 3939 (2014)

[64] H.J. Seo, Y.E. Cho, T. Kim, H.I. Shin, I.S. Kwun, Nutr. Res. Pract. 4, 356 (2010)

[65] J. Xu, G. Ding, J.L. Li, S.H. Yang, B.S. Fang, H.C. Sun, Y.M. Zhou, Appl. Surf. Sci. 256, 7540 (2010)

[66] T.N. Phan, T. Buckner, J. Sheng, J.D. Baldeck, R.E. Marquis, Oral Microbiol. Immunol. 19, 31 (2004)

[67] H. Hu, W. Zhang, Y. Qiao, X. Jiang, X. Liu, C. Ding, Acta Biomater. 8, 904 (2012)

[68] J.N. Li, Y. Song, S.X. Zhang, C.L. Zhao, F. Zhang, X. Zhang, L. Cao, Q.M. Fan, T. Tang, Biomaterials 31, 5782 (2010)

[69] Y. Zhang, J.X. Li, J.Y. Li, J. Alloys Compd. 730, 458 (2018)

[70] A.F. Cipriano, A. Sallee, M. Tayoba, M.C. Cortez Alcaraz, A. Lin, R.G. Guan, Z.Y. Zhao, H.N. Liu, Acta Biomater. 48, 499 (2017)

[71] G.Z. Yang, H.W. Yang, L. Shi, T.L. Wang, W.C. Zhou, T. Zhou, W. Han, Z.Y. Zhang, W. Lu, J.Z. Hu, A.C.S. Biomater, Sci. Eng. 4, 4289 (2018)

[72] G.F. Wang, S.I. Roohani-Esfahani, W.J. Zhang, K.G. Lv, G.Z. Yang, X. Ding, D.R. Zou, D.X. Cui, H. Zreiqat, X.Q. Jiang, Sci. Rep. 7, 1 (2017)

[73] Y.H. Zou, J. Wang, L.Y. Cui, R.C. Zeng, Q.Z. Wang, Q.X. Han, J. Qiu, X.B. Chen, D.C. Chen, S.K. Guan, Y.F. Zheng, Acta Biomater. 98, 196 (2019)

[74] A. Roy, B.S. Butola, M. Joshi, Appl. Clay Sci. 146, 278 (2017)

[75] Z.R. Xu, X.L. Zhao, X.D. Chen, Z.H. Chen, Z.F. Xia, RSC Adv. 7, 52266 (2017)

[76] J.R. Harrington, R.J. Martens, N.D. Cohen, L.R. Bernstein, J. Vet. Pharmacol. Ther. 29, 121 (2006)

[77] L.R. Bernstein, Pharmacol. Rev. 50, 665 (1998)

[78] Z.H. Gao, M.S. Song, R.L. Liu, Y.S. Shen, L. Ward, I. Cole, X.B. Chen, X.C. Liu, Mater. Sci. Eng. C 104, 109926 (2019)

[79] S. Silver, L.T. Phung, G. Silver, J. Ind. Microbiol. Biotechnol. 33, 627 (2006)

[80] G. Gosheger, J. Hardes, H. Ahrens, A. Streitburger, H. Buerger, M. Erren, A. Gunsel, F.H. Kemper, W. Winkelmann, C. Von Eiff, Biomaterials 25, 5547 (2004)

[81] P. Sivakumar, M. Lee, Y.S. Kim, M.S. Shim, J. Mater. Chem. B 6, 4852 (2018)

[82] S. Meghana, P. Kabra, S. Chakraborty, N. Padmavathy, RSC Adv. 5, $12293(2015)$

[83] H. Kong, J. Song, J. Jang, Environ. Sci. Technol. 44, 5672 (2010)

[84] C.J. Chung, H.I. Lin, H.K. Tsou, Z.Y. Shi, J.L. He, J. Biomed. Mater. Res. B 85, 220 (2008)

[85] A.U. Ubale, M.R. Belkhedkar, J. Mater. Sci. Technol 31, 1 (2015)

[86] L.Y. Cui, G. Bin Wei, Z.Z. Han, R.C. Zeng, L. Wang, Y.H. Zou, S.Q. Li, D.K. Xu, S.K. Guan, J. Mater. Sci. Technol. 35, 254 (2019)

[87] M.K. Peng, F.Y. Hu, M.T. Du, B.J. Mai, S.R. Zheng, P. Liu, Mater. Sci. 14, 14 (2020)

[88] K. Bewilogua, D. Hofmann, Surf. Coat. Technol. 242, 214 (2014)

[89] Y. Uematsu, T. Kakiuchi, T. Teratani, Y. Harada, K. Tokaji, Surf. Coat. Technol. 205, 2778 (2011)

[90] G.S. Wu, X. Zhang, Y. Zhao, J.M. Ibrahim, G.Y. Yuan, P.K. Chu, Corros. Sci. 78, 121 (2014)

[91] W.H. Jin, P.K. Chu, Surf. Coat. Technol. 336, 2 (2018)

[92] H.Q. Feng, X.L. Zhang, G.S. Wu, W.H. Jin, Q. Hao, G.M. Wang, Y.F. Huang, P.K. Chu, RSC Adv. 6, 14756 (2016)

[93] C. Chung, Y.K. Kim, D. Shin, S.R. Ryoo, B.H. Hong, D.H. Min, Acc. Chem. Res. 46, 2211 (2013)

[94] M.D. Stoller, S. Park, Y.W. Zhu, J. An, R.S. Ruoff, Nano Lett. 8, 3498 (2008)
[95] A.A. Balandin, S. Ghosh, W. Bao, I. Calizo, D. Teweldebrhan, F. Miao, C.N. Lau, Nano Lett. 8, 902 (2008)

[96] C. Lee, X.D. Wei, J.W. Kysar, J. Hone, Science 321, 385 (2008)

[97] J.J. Qiu, L. Liu, H.Q. Zhu, X.Y. Liu, Bioact. Mater. 3, 341 (2018)

[98] H.R. Bakhsheshi-Rad, E. Hamzah, M. Kasiri-Asgarani, S.N. Saud, F. Yaghoubidoust, E. Akbari, Vacuum 131, 106 (2016)

[99] R.S. El-Kamel, A.A. Ghoneim, A.M. Fekry, Mater. Sci. Eng. C 103, 109780 (2019)

[100] X.F. Zou, L. Zhang, Z.J. Wang, Y. Luo, J. Am. Chem. Soc. 138 2064 (2016)

[101] S. Bin Liu, M. Hu, T.Y.H. Zeng, R. Wu, R.R. Jiang, J. Wei, L. Wang, J. Kong, Y. Chen, Langmuir 28, 12364 (2012)

[102] X. Cai, S.Z. Tan, M.S. Lin, A. Xie, W.J. Mai, X.J. Zhang, Z.D. Lin, T. Wu, Y.L. Liu, Langmuir 27, 7828 (2011)

[103] M. Hrubovčáková, M. Kupková, M. Džupon, M. Giretová, L. Medvecký, R. Džunda, Int. J. Electrochem. Sci. 12, 11122 (2017)

[104] M.M. Umair, Z. Jiang, N. Ullah, W. Safdar, Z. Xie, X. Ren, J. Ind. Text. 46, 59 (2016)

[105] E.I. Rabea, M.E.T. Badawy, C.V. Stevens, G. Smagghe, W. Steurbaut, Biomacromol 4, 1457 (2003)

[106] J. Blacklock, T.K. Sievers, H. Handa, Y.Z. You, D. Oupický, G. Mao, H. Möhwald, J. Phys. Chem. B 114, 5283 (2010)

[107] R. Kumar, M. Oves, T. Ameelbi, N.H. Al-Makishah, M.A. Barakat, J. Colloid Interface Sci. 490, 488 (2017)

[108] M. El Guilli, A. Hamza, C. Clément, M. Ibriz, E.A. Barka, Agriculture (Switzerland) 6, 12 (2016)

[109] K.C. Li, R. Xing, S. Liu, Y.K. Qin, H.H. Yu, P. Li, Int. J. Biol. Macromol. 64, 302 (2014)

[110] H. Ai, F.R. Wang, Y.Q. Xia, X.M. Chen, C.L. Lei, Food Chem 132, 493 (2012)

[111] K. Xing, X. Zhu, X. Peng, S. Qin, Agron. Sustain. Dev. 35, 569 (2015)

[112] B. Wang, L. Zhao, W.W. Zhu, L.M. Fang, F.Z. Ren, Colloids Surf. B 157, 432 (2017)

[113] F.Z. Ren, Y. Leng, Y.H. Ding, K.F. Wang, CrystEngComm 15, $2137(2013)$

[114] D.J. Stickler, J.C. Lear, N.S. Morris, S.M. Macleod, A. Downer, D.H. Cadd, W.J. Feast, J. Appl. Microbiol. 100, 1028 (2006)

[115] R. Wang, K.G. Neoh, Z.L. Shi, E.T. Kang, P.A. Tambyah, E. Chiong, Biotechnol. Bioeng. 109, 336 (2012)

[116] L.Y. Cui, J. Xu, N. Lu, R.C. Zeng, Y.H. Zou, S.Q. Li, F. Zhang, Trans. Nonferrous Met. Soc. China 27, 1081 (2017)

[117] J.H. Fu, J. Ji, W.Y. Yuan, J.C. Shen, Biomaterials 26, 6684 (2005)

[118] H.Y. Wang, Y.K. Feng, H.Y. Zhao, Z.C. Fang, M. Khan, J.T. Guo, J. Nanosci. Nanotechnol. 13, 1578 (2013)

[119] C.H. Wang, Z.L. Yi, Y.F. Sheng, L. Tian, L. Qin, T. Ngai, W. Lin, Mater. Sci. Eng. C 99, 344 (2019)

[120] A. Zomorodian, I.A. Ribeiro, J.C.S. Fernandes, A.C. Matos, C. Santos, A.F. Bettencourt, M.F. Montemor, Int. J. Polym. Mater. Polym. Biomater. 66, 533 (2017)

[121] C. Tan, X.X. Zhang, Q. Li, Biomed. Technol. 62, 375 (2017)

[122] E. Dayaghi, H.R. Bakhsheshi-Rad, E. Hamzah, A. AkhavanFarid, A.F. Ismail, M. Aziz, E. Abdolahi, Mater. Sci. Eng. C 102, 53 (2019)

[123] M.R. Virto, P. Frutos, S. Torrado, G. Frutos, Biomaterials 24, 79 (2003)

[124] X.J. Ji, L. Gao, J.C. Liu, J. Wang, Q. Cheng, J.P. Li, Colloids Surf. B 179, 429 (2019)

[125] X.J. Ji, L. Gao, J.C. Liu, R.Z. Jiang, F.Y. Sun, L.Y. Cui, S.Q. Li, K.Q. Zhi, R.C. Zeng, Z.L. Wang, Prog. Org. Coat. 135, 465 (2019)

[126] M.M. Masadeh, K.H. Alzoubi, O.F. Khabour, S.I. Al-Azzam, Curr. Ther. Res. 77, 14 (2015)

[127] K.V.R. Reddy, R.D. Yedery, C. Aranha, Int. J. Antimicrob. Agents 24, 536 (2004)

[128] K. De Smet, R. Contreras, Biotechnol. Lett. 27, 1337 (2005) 
[129] J.J. Chen, Y.C. Zhu, Y.C. Song, L. Wang, J.Z. Zhan, J.C. He, J. Zheng, C.T. Zhong, X.T. Shi, S. Liu, L. Ren, Y.J. Wang, J. Mater. Chem. B 5, 2407 (2017)

[130]Z.Z. Yin, W.C. Qi, R.C. Zeng, X.B. Chen, C.D. Gu, J. Mag. Alloys 8, 42 (2020)

[131] L. Li, A.A. Shaik, J. Zhang, K. Nhkata, L. Wang, Y. Zhang, C. Xing, S.H. Kim, J. Lü, J. Pharm. Biomed. Anal. 54, 545 (2011)

[132] A. Scalbert, Phytochemistry 30, 3875 (1991)

[133] A. Mori, C. Nishino, N. Enoki, S. Tawata, Phytochemistry 26, 2231 (1987)

[134] M. Daglia, Curr. Opin. Biotechnol. 23, 174 (2012)

[135] L.Y. Cui, H.P. Liu, K. Xue, W. Le Zhang, R.C. Zeng, S.Q. Li, D. Kui Xu, E.H. Han, S.K. Guan, J. Electrochem. Soc. 165, C821 (2018)

[136] P. Widsten, C. Heathcote, A. Kandelbauer, G. Guebitz, G.S. Nyanhongo, E.N. Prasetyo, T. Kudanga, Process Biochem. 45, 1072 (2010)

[137] H. Ejima, J.J. Richardson, K. Liang, J.P. Best, M.P. Van Koeverden, G.K. Such, J. Cui, F. Caruso, Science 341, 154 (2013)

[138] J.X. Chen, Y. Zhang, M. Ibrahim, I.P. Etim, L.L. Tan, K. Yang, Colloids Surf. B 179, 77 (2019)

[139] Y.J. Hu, Y.Z. Bi, D.L. He, H.Y. Yu, Y. Li, Surf. Technol. 48, $11(2019)$

[140] Y.Y. Pei, Q. Song, P. Li, Surf. Technol. 48, 200 (2019)

[141] K.K. Chung, J.F. Schumacher, E.M. Sampson, R.A. Burne, P.J. Antonelli, A.B. Brennan, Biointerphases 2, 89 (2007)

[142] M. Miyazaki, H. Moriya, A. Miyauchi, J. Photopolym. Sci. Technol. 32, 295 (2019)

[143] S.T. Reddy, K.K. Chung, C.J. McDaniel, R.O. Darouiche, J. Landman, A.B. Brennan, J. Endourol. 25, 1547 (2011)

[144] G. Decher, J.D. Hong, J. Schmitt, Thin Solid Films 210-211, $831(1992)$

[145] X.Y. Zhu, X.J. Loh, Biomater. Sci. 3, 1505 (2015)

[146] Y.B. Zhao, L.Q. Shi, X.J. Ji, J.C. Li, Z.Z. Han, S.Q. Li, R.C. Zeng, F. Zhang, Z.L. Wang, J. Colloid Interface Sci. 526, 43 (2018)

[147] L.Y. Cui, X.H. Fang, W. Cao, R.C. Zeng, S.Q. Li, X.B. Chen, Y.H. Zou, S.K. Guan, E.H. Han, Appl. Surf. Sci. 457, 49 (2018)

[148] L.H. Liu, P.P. Li, Y.H. Zou, K.J. Luo, F. Zhang, R.C. Zeng, S.Q. Li, Surf. Coat. Technol. 291, 7 (2016)

[149] Y.H. Gu, C.F. Chen, S. Bandopadhyay, C.Y. Ning, Y.J. Zhang, Y.J. Guo, Appl. Surf. Sci. 258, 6116 (2012)

[150] L. Ren, X. Lin, L.L. Tan, K. Yang, Mater. Lett. 65, 3509 (2011)

[151] E. Padan, E. Bibi, M. Ito, T.A. Krulwich, Biochim. Biophys. Acta Biomembr. 1717, 67 (2005)

[152] E.A. Abou Neel, I. Ahmed, J. Pratten, S.N. Nazhat, J.C. Knowles, Biomaterials 26, 2247 (2005)

[153] M. Yazici, A.E. Gulec, M. Gurbuz, Y. Gencer, M. Tarakci, Thin Solid Films 644, 92 (2017)

[154] S. Gheytani, Y. Liang, Y. Jing, J.Q. Xu, Y. Yao, J. Mater. Chem. A 4, 395 (2015)

[155] B. Vellaichamy, P. Periakaruppan, B. Nagulan, ACS Sustainable Chem. Eng. 5, 9313 (2017)

[156] X. Yang, P. Huang, H.H. Wang, S. Cai, Y.X. Liao, Z.Q. Mo, X.Y. Xu, C.M. Ding, C.S. Zhao, J.S. Li, Colloids Surf. B 160, 136 (2017)

[157] T.T. Yan, L.L. Tan, B.C. Zhang, K. Yang, J. Mater. Sci. Technol. 30, 666 (2014)

[158] G.W. Hu, L.C. Zeng, H. Du, X. De Fu, X.X. Jin, M. Deng, Y.J. Zhao, X.W. Liu, Surf. Coat. Technol. 325, 127 (2017)

[159] M.T. Du, L.L. Huang, M.K. Peng, F.Y. Hu, Q. Gao, Y.S. Chen, P. Liu, Thin Solid Films 693, 137679 (2019)

[160] M.Q. Cheng, Y.Q. Qiao, Q. Wang, H. Qin, X.L. Zhang, X.Y. Liu, Colloids Surf. B 148, 200 (2016)
[161] J.D. Ehrman, E.T. Bender, N. Stojilovic, T. Sullivan, R.D. Ramsier, B.W. Buczynski, M.M. Kory, R.P. Steiner, Colloids Surf. B 50, 152 (2006)

[162] M. Li, M.J. Mondrinos, X. Chen, M.R. Gandhi, F.K. Ko, P.I. Lelkes, J. Biomed. Mater. Res. A 79, 963 (2006)

[163] S. Agarwal, J. Curtin, B. Duffy, S. Jaiswal, Mater. Sci. Eng. C 68, 948 (2016)

[164] L. Chen, J.A. Li, J.W. Chang, S.B. Jin, D. Wu, H.H. Yan, X.F. Wang, S.K. Guan, Sci. China Technol. Sci. 61, 1228 (2018)

[165] H. Hornberger, S. Virtanen, A.R. Boccaccini, Acta Biomater. 8, 2442 (2012)

[166] F. Witte, J. Fischer, J. Nellesen, C. Vogt, J. Vogt, T. Donath, F. Beckmann, Acta Biomater. 6, 1792 (2010)

[167] Y.Q. Yu, G.D. Jin, Y. Xue, D.H. Wang, X.Y. Liu, J. Sun, Acta Biomater. 49, 590 (2017)

[168] H.Z. Dong, D.K. Li, D.Y. Mao, N.N. Bai, Y.S. Chen, Q. Li, Appl. Surf. Sci. 435, 320 (2018)

[169] B.G.X. Zhang, D.E. Myers, G.G. Wallace, M. Brandt, P.F.M. Choong, Int. J. Mol. Sci. 15, 11878 (2014)

[170] W. Ahmed, Z. Zhai, C. Gao, Mater. Today Bio. 2, 100017 (2019)

[171] Y. Imai, K.J. Meyer, A. Iinishi, Q. Favre-Godal, R. Green, S. Manuse, M. Caboni, M. Mori, S. Niles, M. Ghiglieri, C. Honrao, X. Ma, J. Guo, A. Makriyannis, L. Linares-Otoya, N. Böhringer, Z.G. Wuisan, H. Kaur, R. Wu, A. Mateus, A. Typas, M.M. Savitski, J.L. Espinoza, A. O'Rourke, K.E. Nelson, S. Hiller, N. Noinaj, T.F. Schäberle, A. D'Onofrio, K. Lewis, Nature 576, 459 (2019)

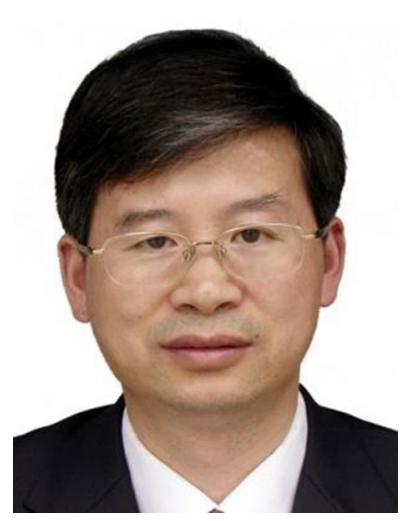

Prof. Rong-Chang Zeng obtained his Ph.D degree at the Institute of Metals Research, Chinese Academy of Sciences in August 2003. During July 2003-Jun. 2010, he worked in Chongqing University of Technology, China. From March 2006 to February 2007, Dr. Zeng studied in Helmholtz-Zentrum Geesthacht (HZG) in Germany as a visiting scientist. Since June 2010, Prof. Zeng has been employed as a professor by Shandong University of Science and Technology, China, and the head of research group "Corrosion and Protection of Materials" and corrosion laboratory for light metals. Prof. Zeng is the member of the editorial boards or guest editor of seven peer-reviewed journals, i.e., Journal of Magnesium and Alloys, Frontier of Materials Science and Heliyon, and peer reviewer of more than 40 journals. He became 2019 Publons Top reviewers in Materials Science and Cross-Field. He has authored/coauthored $150+$ SCI papers, six books/book chapters and 30 patents. He is an adjunct Professor at Xi' an Jiaotong University (2017-Present) and Wuhan University of Technology (2018-present), and a member of China Magnesium Association (CMA) (2003-Present), council member of Chinese Society for Corrosion and Protection (CSCP) (2017-Present), Chinese Committee for Magnesium and its Application (CCMA) (2015-Present), Committee for Metallic Branch of Chinese society of biomaterials (2014-Present) and Vice-Chairman for Shandong Province Society for Corrosion and Protection (2018-Present). His current interest is focused on corrosion and functional surface modification of biodegradable magnesium alloys. 